УДК 342.9

DOI https://doi.org/10.32849/2663-5313/2020.3.32

\title{
Павло Яковлев,
}

канд. юрид. наук, докторант

Харківського національного університету імені В. Н. Каразіна

\section{ПРАВОВИЙ РЕЖИМ ДЕРЖАВНОЇ МОВИ У СФЕРІ ЗАБЕЗПЕЧЕННЯ ІНФОРМАЦИЙНОЇ БЕЗПЕКИ}

У статті розглядається правовий режим української мови як державної з позицій державного регулювання у сфері забезпечення інформачійної безпеки. Розкрито значення державної мови як одного з визначальних факторів начіональної безпеки. Окремо виділено ті аспекти інформаційної безпеки як складової частини начіональної безпеки, для забезпечення яких має значення державна мова. Зокрема, акиентовано увагу на окремих аспектах використання державної мови для захисту інформаиії в умовах протидії збройній агресії, а також обмеження можливостей і ефективності поширення негативних інформаиійно-культурних впливів ворожої, антиукраїнської пропаганди. Правовий режим державної мови розглянуто із традиійних для науки адміністративного права поглядів на зміст категорій «правовий режим» та «адміністративно-правовий режим».

Досліджено основні складові частини правового режиму державної мови, зокрема такі, як:правила застосування держсвної мови у Збройних Силах України та інших військових формуваннях, а також в органах правопорядку, розвідувальних органах, державних органах спечіального призначення із правоохоронними функціями, вимоги щодо обов'язкового (мінімального) обсягу мовлення державною мовою для телерадіоорганізацій окремих категорій мовлення, вимоги щодо видання друкованих засобів масової інформачії в Україні державною мовою, державний контроль за дотриманням зазначених правил та вимог, здійснюваний Уповноваженим із захисту державної мови та Начіональною радою з питань телебачення і радіомовлення; юридична відповідальність за порушення зазначених правил та вимог, притягнення до якої здійснюється Уповноваженим із захисту державної мови та Національною радою з питань телебачення і радіомовлення. Акиентовано увагу на адміністративно-правовій природі даного режиму.

Як правову основу для визначення змісту правового режиму державної мови використано Закони України «Про забезпечення функиіонування української мови як державної» та «Про телебачення і радіомовлення», а також відповідні положення чинних сьогодні Кониепції державної мовної політики та Доктрини інформаційної безпеки України.

Ключові слова: національна безпека, інформаційна безпека, державна мова, правовий режим державної мови, державне регулювання у сфері інформаційної безпеки.

Постановка проблеми. Із початком збройної агресії РФ проти України актуалізувалося питання забезпечення національної безпеки взагалі та інформаційної безпеки зокрема. Проблема забезпечення інформаційної безпеки в Україні є надзвичайно багатоаспектною і залежить від багатьох чинників. Одним із них є використання державної мови. Останнім часом в Україні було ухвалено декілька законів та інших правових актів, спрямованих на посилення статусу української мови як державної та запровадження такого правового режиму державної мови, який би зробив ії потужним фактором національної безпеки. Фактично з нуля було створено механізм державного регулювання у сфері національної безпеки в її інформаційній частині, в тому числі з використанням можливостей державної мови. Відтак потре- бує дослідження та відповідного наукового осмислення створений правовий режим державної мови як засобу державного регулювання у сфері інформаційної безпеки.

Важливість дослідження зазначеного питання зумовлюється необхідністю досягнення таких результатів державного регулювання у сфері забезпечення інформаційної безпеки, які б на практиці продемонстрували покращення її рівня, а відтак посилили б стан національної безпеки в цілому.

Аналіз останніх досліджень та публікацій. Проблемам забезпечення інформаційної безпеки в Україні присвячена досить велика кількість наукових праць, зокрема таких дослідників, як: I. Аристова, К. Беляков, В. Бєлєвцева, І. Доронін, Б. Кормич, В. Конах, О. Левченко та ін. 3 іншого боку, існуе й велика кількість публікацій, присвячених 
державній мові як фактору національної безпеки, серед яких варто відзначити праці В. Демченка, Л. Масенко, Т. Усатенко, М. Чеховської, В. Шлапаченка та інших Водночас публікацій, присвячених правовому статусу та правовому режиму державної мови, особливо в контексті забезпечення інформаційної безпеки, майже немає. Певною мірою це зумовлено тим, що законодавство, яким визначається зазначений правовий режим, з'явилося відносно недавно і відповідні проблеми ще не потрапили в поле зору науковців.

Метою статті є з'ясування змісту та складових частин правового режиму державної мови як засобу державного регулювання у сфері забезпечення інформаційної безпеки з визначенням тих аспектів інформаційної безпеки як складової частини національної безпеки, для забезпечення яких має значення державна мова.

Виклад основного матеріалу. Проблема використання державної мови в контексті забезпечення інформаційної безпеки набула надзвичайної гостроти 3 початком збройної агресії РФ проти України у 2014 році, хоча в поле зору дослідників ця проблема потрапляла й раніше.

Як справедливо зазначає В. М. Демченко, серед чинників державної безпеки поряд з інформаційним (захист українського інформаційного простору - телебачення, радіо, Інтернет - від стороннього впливу); освітнім (захист українського освітнього простору від стороннього впливу), науковим (підтримка й розвиток національних наукових структур), культурним (забезпечення розвитку національної культури), релігійним (забезпечення безперешкодного функціонування української церкви) постає мовний, що передбачає забезпечення безперешкодного функціонування української державної мови в усіх сферах соціального життя. Мовний чинник стоїть в означеному комплексі національної безпеки на першому місці, оскільки присутній у кожному 3 названих факторів: медіа-засоби функціонують у вербальній реалізації, освіта та наука просто мусять функціонувати державною мовою, і розвиток такої ж наукової метамови на часі. Культурний же чинник безпосередньо пов'язаний з українською мовою, що у сферах фольклору, музики та літератури відіграє визначальну роль [6].

Як відзначалося в Концепції державної мовної політики, схваленої Указом Президента України від 15 лютого 2010 року № 161/2010 [3], незважаючи на задекларованість державного статусу української мови, аналіз мовної ситуації в державі свідчить про наявність політичних спекуляцій щодо iii використання, що суперечить інтересам національної безпеки України, ставить під загрозу іiї суверенітет. Для усунення такої загрози необхідно розширити сферу застосування української мови, стимулювати формування і захист національного мовно-культурного та мовно-інформаційного простору. Держава повинна забезпечити безумовне виконання конституційної норми про всебічний розвиток і функціонування української мови в усіх сферах суспільного життя на всій території України.

У цьому документі прямо не вказано на зв'язок стану державної мови та національної безпеки, але позитивним є те, що практично визнано той факт, що мовна ситуація в державі суперечить інтересам національної безпеки України, ставить під загрозу їі суверенітет. А вже у Стратегії популяризації української мови до 2030 року «Сильна мова - успішна держава», схваленій розпорядженням Кабінету Міністрів України від 17 липня 2019 р. № 596-р [5], прямо зазначено, що розвиток і функціонування української мови як державної в усіх сферах суспільного життя на всій території України $€$ важливим елементом забезпечення національної безпеки та національних інтересів України.

Далі, відповідно до Доктрини інформаційної безпеки України, затвердженої Указом Президента України від 25 лютого 2017 року № 47/2017 [4], до життєво важливих інтересів суспільства і держави як складової частини національних інтересів в інформаційній сфері відноситься забезпечення всебічного розвитку і функціонування української мови в усіх сферах суспільного життя на всій території України.

Нарешті, у 2019 році у частині восьмій статті 1 Закону України «Про забезпечення функціонування української мови як державної» [1] було закріплено положення про те, що українська мова як єдина державна мова виконує функції мови міжетнічного спілкування, є гарантією захисту прав людини для кожного українського громадянина незалежно від його етнічного походження, а також $є$ фактором єдності і національної безпеки України. У свою чергу, в п. 3 частини першої статті 3 цього ж закону було зазначено, що поряд 3 іншим метою цього закону є забезпечення функціонування державної мови як інструмента об'єднання українського суспільства, засобу зміцнення державної єдності та територіальної цілісності України, її незалежної державності і національної безпеки. 
Відтак можна стверджувати, що на законодавчому рівні державна українська мова визнана фактором інформаційної безпеки як складової частини національної безпеки. Але визнати за українською мовою відповідний статус хоча й дуже важливо, проте недостатньо для забезпечення інформаційної безпеки. Необхідно створити відповідний правовий режим, у межах якого буде створений механізм реальної протидії загрозам в інформаційній сфері, який буде здатний їх мінімізувати через його реалізацію.

Як зазначають дослідники, державна мова $\epsilon$ потужним безпековим чинником, основними ознаками-проявами якого $є$ утвердження єдиної національної ідентифікації та консолідація українського суспільства на базі єдиного мовно-культурного простору; усвідомлення окремішності, самостійності та самодостатності своєї нації-держави, піднесення патріотизму; обмеження можливостей i ефективності поширення негативних інформаційно-культурних впливів «руського мира» [7, с. 44].

Саме на останньому прояві зазначеного безпекового чинника і зосередимо подальшу увагу.

Не вдаючись до дискусії стосовно змісту терміна «правовий режим», зазначимо, що, на нашу думку, найбільш точним є розуміння правового режиму як закріпленого в нормах права особливого поєднання юридичного інструментарію (юридичних засобів), що характеризується наявністю визначених умов, конкретністю (визначеністю) суспільних відносин, відносністю до визначеного об'єкта і яке переслідує сприятливу, корисну для суспільства і держави ціль [8, с. 37].

Як зазначає С. О. Кузніченко, сьогодні можна відокремити такі основні ознаки спеціальних (вторинних) правових режимів:

1) закріплюються в нормативно-правових актах;

2) забезпечуються та охороняються державою

3) специфічним образом регламентують конкретні галузі суспільних відносин, відокремлюючи конкретні види діяльності, що пов'язана з особливо значимими об'єктами правового регулювання;

4) представляє собою особливий порядок правого регулювання, що складається із сукупності юридичних засобів (дозволів, заборон, позитивних зобов'язань та нетипових правових приписів (презумпції, фікції, дефініції та ін.) і характеризується визначеним їх угрупуванням, що задає певний напрямок регулювання;

5)є сукупністю матеріальних і процедурно-процесуальних норм;
6) має чітко визначену мету регулювання;

7) створює конкретну ступінь сприятливості чи несприятливості (сукупність обмежень та пільг) для задоволення інтересів суб'єктів права [9, с. 110].

Власне всі ці ознаки притаманні правовому режиму української мови як державної, і цей правовий режим можна розглядати в тому числі і в контексті державного регулювання у сфері забезпечення інформаційної безпеки. Тобто можна вести мову про переважно адміністративно-правову природу зазначеного режиму.

Основою правового режиму української мови як єдиної державної мови в Україні $є$ положення частини сьомої статті 1 Закону України «Про забезпечення функціонування української мови як державної», в якій зазначено, що статус української мови як єдиної державної мови передбачає обов'язковість її використання на всій території України під час здійснення повноважень органами державної влади та органами місцевого самоврядування, а також в інших публічних сферах суспільного життя, які визначені цим Законом.

Із точки зору забезпечення інформаційної безпеки найбільший інтерес представляють ті положення згаданого закону, які дають можливість зменшити вплив ворожої пропаганди на громадян України, а також забезпечити достовірне інформування громадян України про різноманітні події суспільнополітичного життя. Насамперед йдеться про режим використання державної мови у сфері телебачення і радіомовлення та у сфері друкованих засобів масової інформації.

Відповідно до статті 24 Закону України «Про забезпечення функціонування української мови як державної» телерадіоорганізації здійснюють мовлення державною мовою. Обов'язковий (мінімальний) обсяг мовлення державною мовою для телерадіоорганізацій окремих категорій встановлюється Законом України «Про телебачення і радіомовлення» [2].

Відповідно до частини сьомої статті 9 Закону України «Про телебачення і радіомовлення» під час проведення конкурсів на видачу ліцензії на мовлення Національна рада з питань телебачення та радіомовлення поряд 3 іншим керується необхідністю захисту інтересів держави, протидії інформаційній агресії та розвитку державної мови. Частиною першою статті 10 цього закону встановлено, що телерадіоорганізації здійснюють мовлення державною мовою. Обов'язковий (мінімальний) обсяг мовлення державною мовою для телерадіоорганізацій окремих категорій мовлення встановлюється цим Законом. Наприклад, відповідно до частини другої цієї 
статті в загальному тижневому обсязі мовлення телерадіоорганізацій загальнонаціональної і регіональної категорій мовлення які відповідно до ліцензій здійснюють ефірне та/або багатоканальне (цифрове) мовлення 3 використанням радіочастотного ресурсу, передачі та/або фільми, виконані державною мовою, мають становити не менше 75 відсотків загальної тривалості передач та/або фільмів (або їх частин) у кожному проміжку часу між 07.00 та 18.00 і між 18.00 та 22.00. Тобто складовою частиною правового режиму державної мови у сфері телебачення і радіомовлення $є$ вимоги щодо розміру частки тривалості передач та/або фільмів, які транслюються державною мовою.

Що стосується правового режиму державної мови у сфері друкованих засобів масової інформації, то відповідно до частини першої статті 25 Закону України «Про забезпечення функціонування української мови як державної» друковані засоби масової інформації в Україні видаються державною мовою. Друковані засоби масової інформації можуть видаватися іншими, ніж державна, мовами за умови, що одночасно з відповідним тиражем видання іноземною мовою видається тираж цього видання державною мовою. Усі мовні версії повинні видаватися під однаковою назвою, відповідати одна одній за змістом, обсягом та способом друку, а їх випуски повинні мати однакову нумерацію порядкових номерів і видаватися в один день.

Ще одним важливим аспектом правового режиму державної мови в контексті забезпечення інформаційної безпеки є правила застосування державної мови у Збройних Силах України та інших військових формуваннях, а також в органах правопорядку, розвідувальних органах, державних органах спеціального призначення із правоохоронними функціями. Цим питанням присвячені статті 15 та 163 Закону України «Про забезпечення функціонування української мови як державної».

Відповідно до статті 15 згаданого закону мовою нормативних актів, документації, діловодства, команд, навчання, виховних заходів, іншого статутного спілкування та службової діяльності у Збройних Силах України та інших військових формуваннях, створених відповідно до закону, є державна мова. Аналогічне правило закріплене й у статті 16, відповідно до якої мовою нормативних актів, документації, діловодства, службової діяльності та спілкування із громадянами України в органах правопорядку, розвідувальних органах, державних органах спеціального призначення із правоохоронними функціями є державна мова.

Використання української мови в зазначених сферах переслідує декілька цілей у контексті забезпечення інформаційної безпеки. По-перше, використання державної мови, відмінної від мови країни агресора, ускладнює розвідувальну діяльність 3 боку останньої. Навіть за умов, що українська мова має багато спільних рис із російською, досвід показує, що людина, яка не є вихідцем із україномовного чи білінгвального середовища, досить погано розуміє і документи, і розмови, що ведуться українською мовою. Це певною мірою сприяє захисту інформації у відповідному середовищі.

По-друге, рівень володіння державною мовою є своєрідним ідентифікатором у системі «свій - чужий», і такий ідентифікатор часто дозволяє відрізнити інформацію, сформовану ворогом, від автентичної україномовної інформації. Тут має значення і стиль викладення інформації, і застосування різноманітних граматичних форм, властивих український мові, і правильне використання слів тощо.

У наведених випадках ми спостерігаємо, що регулюючий вплив досягається за рахунок встановлення відповідних обов'язків щодо використання державної мови. Але, крім цього, складовими частинами правового режиму державної мови є контроль за дотриманням відповідних правил, а також юридична відповідальність за їх порушення.

Так, відповідно до статті 56 Закону України «Про забезпечення функціонування української мови як державної» Уповноважений із захисту державної мови здійснює державний контроль за застосуванням державної мови у випадку, визначеному частиною третьою статті 55 цього Закону, а також за власною ініціативою. Предметом здійснення державного контролю за застосуванням державної мови $€$ дотримання визначених цим Законом вимог застосування державної мови. Порядок здійснення державного контролю за застосуванням державної мови органами державної влади, органами влади Автономної Республіки Крим, органами місцевого самоврядування, суб'єктами господарювання, іншими юридичними особами та їх посадовими особами встановлюється цим Законом. Також відповідно до статті 70 Закону України «Про телебачення і радіомовлення» Національна рада 3 питань телебачення і радіомовлення здійснює контроль за дотриманням та забезпечує виконання вимог законодавства України у сфері телебачення і радіомовлення.

Що стосується юридичної відповідальності, то статтею 188-52 Кодексу України про адміністративні правопорушення передбачено адміністративну відповідальність за порушення закону щодо функціонування і застосування української мови як державної. 
Зокрема, частиною першої цієї статті встановлено, що порушення вимог Закону України «Про забезпечення функціонування української мови як державної» щодо застосування державної мови під час засідань, заходів, зустрічей і робочого спілкування, в актах, діловодстві та документообігу в органах державної влади, органах влади Автономної Республіки Крим і органах місцевого самоврядування, на державних і комунальних підприємствах, в установах та організаціях, інших суб'єктах господарювання державної і комунальної форми власності, в судочинстві та діловодстві в судах України, в органах правопорядку, розвідувальних органах, державних органах спеціального призначення із правоохоронними функціями, на державному кордоні України, у процесі виборів та референдумів, у міжнародних договорах України - тягнуть за собою накладення штрафу від двохсот до чотирьохсот неоподатковуваних мінімумів доходів громадян або попередження, якщо порушення вчинене вперше.

Адміністративно-юрисдикційними повноваженнями наділена i Національна рада 3 питань телебачення i радіомовлення. Так, відповідно до частини першої статті 72 Закону України «Про телебачення і радіомовлення» санкції за порушення законодавства про телебачення і радіомовлення застосовуються за рішенням суду або, у встановлених цим Законом випадках, за рішенням Національної ради. Відповідно до частини шостої цієї ж статті Національна рада може застосовувати до телерадіоорганізацій та провайдерів програмної послуги такі санкції: оголошення попередження; стягнення штрафу; анулювання ліцензії на підставі рішення суду за позовом Національної ради.

Що стосується відповідальності за невиконання вимог щодо квот державної мови, то частиною 11 зазначеної статті встановлено, що за невиконання вимог, встановлених статтею 10 цього Закону, телерадіоорганізація, що здійснюе мовлення, сплачуе штраф у розмірі 5 відсотків загальної суми ліцензійного збору ліцензії, виданої відповідно до ліцензії на мовлення.

\section{Висновки}

Підсумовуючи викладене, можна стверджувати, що правовий режим державної мови можна розглядати як один із засобів державного регулювання у сфері забезпечення інформаційної безпеки. Складовими частинами цього правового режиму в контексті забезпечення інформаційної безпеки є: правила застосування державної мови у Збройних Силах України та інших військових формуваннях, а також в органах правопорядку, розвідуваль- них органах, державних органах спеціального призначення із правоохоронними функціями; вимоги щодо обов'язкового (мінімального) обсягу мовлення державною мовою для телерадіоорганізацій окремих категорій мовлення; вимоги щодо видання друкованих засобів масової інформації в Україні державною мовою; державний контроль за дотриманнями зазначених правил та вимог, здійснюваний Уповноваженим із захисту державної мови та Національною радою з питань телебачення і радіомовлення; юридична відповідальність за порушення зазначених правил та вимог, притягнення до якої здійснюється Уповноваженим із захисту державної мови та Національною радою з питань телебачення і радіомовлення. Зміст цих складових частин дає можливість констатувати адміністративноправову природу даного режиму

\section{Список використаних джерел:}

1. Про забезпечення функціонування української мови як державної. Закон України від 25 квітня 2019 року № 2704-VIII. Відомості Верховної Ради України. 2019 р. № 21. С. 5. Ст. 81.

2. Про телебачення і радіомовлення : Закон України від 21 грудня 1993 року № 3759-XII. Відомості Верховної Ради Украӥни. 1994 р. № 10. Ст. 43.

3. Про концепцію державної мовної політики. Указ Президента України від 15 лютого 2010 року N 161/2010. Офіиійний вісник України. 2010. № 13. С. 16. Ст. 601.

4. Про рішення Ради національної безпеки і оборони України від 29 грудня 2016 року «Про Доктрину інформаційної безпеки України» : Указ Президента України від 25 лютого 2017 року № $47 / 2017$.

5. Про схвалення Стратегії популяризації української мови до 2030 року «Сильна мова успішна держава». Розпорядження Кабінету Міністрів України від 17 липня 2019 р. № 596-р. Офіиійний вісник Украӥни. 2019. № 62. С. 62. Ст. 2159.

6. Демченко В. М. Українська мова як фактор державної безпеки. Теорія та практика державного управління і місиевого самоврядування. 2016. № 2. URL: http://el-zbirn-du.at.ua/2016_2/6.pdf (дата звернення: 12.02.2020)

7. Чеховська М. М., Шлапаченко В. М. Мова як чинник національної безпеки. Держава та регіони. Серія «Право». 2018. № 3(61). C. 39-46. URL: http:// law.stateandregions.zp.ua/archive/3_2018/9.pdf (дата звернення: 12.02.2020).

8. Адабаш О. В. Поняття, сутність та ознаки адміністративно-правових режимів. Європейські перспективи. 2013. № 12. С. 36-40.

9. Кузніченко С. О. Феномен правового режиму в адміністративному праві. Форум права. 2007. № 1. C. 109-112. URL: http:// www.nbuv.gov.ua/e-journals/FP/2007-1/07ksovap. pdf (дата звернення: 12.02.2020). 
The article deals with the legal regime of the Ukrainian language as a state language from the standpoint of state regulation in the field of information security. The importance of the state language as one of the determining factors of national security is revealed. The aspects of information security, as a component of national security, for which state language is important, are singled out. In particular, attention is paid to certain aspects of the use of the state language to protect information in the conditions of counteraction to armed aggression, as well as to limit the possibilities and effectiveness of spreading negative information and cultural influences of hostile, anti-Ukrainian propaganda. The legal regime of the state language is considered from the traditional views of the content of the categories "legal regime" and "administrative-legal regime" in the traditional science of administrative law.

The basic components of the legal regime of the state language, in particular, such as the rules for the use of the state language in the Armed Forces of Ukraine and other military formations, as well as in law enforcement agencies, intelligence agencies, state bodies of special purpose with law enforcement functions, requirements for mandatory (minimum) volume of broadcasting in the state language for broadcasting organizations of certain categories of broadcasting, requirements for the publication of print media in the Ukrainian language, state control over compliance these rules and requirements, implemented by the Commissioner for the Protection of the state language and the National Council on Television and Radio Broadcasting; legal responsibility for the violation of these rules and requirements, which are brought to the attention of the Commissioner for the Protection of the State Language and the National Council for Television and Radio Broadcasting. Attention is drawn to the administrative and legal nature of the regime.

The legal basis for determining the content of the legal regime of the state language was used by the Laws of Ukraine "On Ensuring the Functioning of the Ukrainian Language as State" and "On Television and Radio Broadcasting", as well as the relevant provisions of the State Language Policy Concept and the Information Security Doctrine of Ukraine.

Key words: national security, informational security, official language, legal regime of the state language, state regulation in the field of information security. 